\title{
STRUCTURE AND PROPERTIES OF LASER-BEAM-WELDED JOINTS OF LOW-ALLOY HIGH-STRENGTH STEEL DOCOL 1200M WITH A MARTENSITIC STRUCTURE
}

\author{
STRUKTURA IN LASTNOSTI LASERSKO VARJENIH SPOJEV \\ MALOLEGIRANEGA VISOKOTRDNOSTNEGA JEKLA DOCOL \\ 1200M Z MARTENZITNO MIKROSTRUKTURO
}

\author{
Jacek Górka ${ }^{1}$, Andrzej Ozgowicz ${ }^{2}$ \\ ${ }^{1}$ Silesian University of Technology, The Chair of Welding, 18a Konarskiego Street, 44-100 Gliwice, Poland \\ ${ }^{2}$ Styvo AS, Vipevegen 8, N-6783 Stryn, Norway \\ jacek.gorka@polsl.pl \\ Prejem rokopisa - received: 2017-06-20; sprejem za objavo - accepted for publication: 2017-08-03
}

doi:10.17222/mit.2017.077

\begin{abstract}
This article presents studies on the effects of the linear energy of the laser-beam welding of the DOCOL 1200M high-strength low-alloy steel with a martensitic structure, 1.8-mm thick, on the properties and structural changes of the joint area. The welding process was carried out in the horizontal position, without a filler material, at a variable linear energy of the welding ranging from $25 \mathrm{~J} / \mathrm{mm}$ to $55 \mathrm{~J} / \mathrm{mm}$. The non-destructive testing allowed the joints to be classified as the quality level B in accordance with ISO 13919-1. In order to determine the structural changes and changes in the properties, the joints were subjected to destructive testing including macro- and microscopic metallographic examinations, a hardness measurement, a static bend test with the face and root of the weld in tension and a static tensile test. The destructive testing showed that with an increase in the linear energy of the welding, the plastic properties of the joints are enhanced while, at the same time, their strength properties are reduced to the values below that of the base material. The results showed that with the use of the lowest linear energies of laser-beam welding (around $25 \mathrm{~J} / \mathrm{mm}$ ), it is possible to produce welded joints of the DOCOL 1200M steel, whose strength is equal to that of the base material, which is not achievable when arc welding the steels with such a high strength (1200 MPa). The joints made with the liner energy of $25 \mathrm{~J} / \mathrm{mm}$ were characterised by a tensile strength of about $1240 \mathrm{MPa}$, obtaining a bending angle of $70^{\circ}$. The weld hardness was about $440 \mathrm{HV} 1$ and it was similar to that of the base material while in HAZ, the hardness decreased to $360 \mathrm{HV} 1$.
\end{abstract}

Keywords: martensitic steel, DOCOL 1200M, laser welding, linear energy of welding, martensite

V pričujočem članku avtorji predstavljajo študijo vplivov linearne energije varjenja z laserskim snopom na malolegirano jeklo z martenzitno mikrostrukturo vrste DOCOL $1200 \mathrm{M}$. Raziskovali so lastnosti in strukturne spremembe po varjenju v področju 1.8 $\mathrm{mm}$ debelega zvara. Postopek varjenja so izvedli v vodoravnem položaju, brez polnilnega materiala in pri spreminjanju linearne energije varjenja med $25 \mathrm{~J} / \mathrm{mm}$ in $55 \mathrm{~J} / \mathrm{mm}$. Neporušne preiskave zvarov so omogočile njihovo uvrstitev v kakovostni nivo B v skladu z ISO 13919-1. Da bi določili strukturne spremembe in spremembe lastnosti v preiskovanem materialu so bili izdelani zvari izpostavljeni tudi porušnim preiskavam. Te so obsegale makro- in mikroskopske metalografske preiskave, meritve trdote, statični upogibni preizkus na čelu in v korenu zvarov, ter statični natezni preizkus. Porušne preiskave so pokazale, da se z naraščajočo linearno energijo varjenja izboljšajo plastične lastnosti zvarov, medtem ko se istočasno trdnostne lastnosti zmanjšajo pod vrednosti, ki jih ima osnovni material. Rezultati so pokazali, da je bilo možno z uporabo najnižjih linearnih energij varjenja z laserskim snopom (okoli $25 \mathrm{~J} / \mathrm{mm}$ ), variti jeklo DOCOL 1200M s trdnostjo enako osnovnemu materialu, kar ni dosegljivo pri obločnem varjenju s takšno visoko trdnostjo (1200 MPa). Zvari, izdelani z linearno energijo $25 \mathrm{~J} / \mathrm{mm}$, so imeli natezno trdnost okoli $1240 \mathrm{MPa}$ in upogibni kot $70^{\circ}$ po upogibnem preizkusu. Trdota zvarov je bila približno $440 \mathrm{HV} 1$ in enaka tisti, ki jo je imel osnovni material, medtem ko je trdota v toplotno vplivani coni (HAZ; angl.: Heat Affected Zone) padla na 360 HV1.

Ključne besede: martenzitno jeklo, DOCOL 1200M, lasersko varjenje, linearna energija varjenja, martenzit

\section{INTRODUCTION}

Steel producers manufacture newer and newer materials with enhanced properties as a response to the need of, but not limited to, the automotive industry. The reasons are high requirements related to the safety of users and a continuous trend towards reducing the weight of manufactured structures. This development allows a considerable reduction in the weight of vehicles, their fuel consumption and emissions of harmful gases to the environment. To meet this demand of the automotive industry, advanced high-strength steels (AHSSs) were developed. These materials have performed very well in the production of vehicles due to three very important features: a high tensile strength, up to $1700 \mathrm{MPa}$; a high yield point, up to $1450 \mathrm{MPa}$; and a high elongation A80, up to $30 \% .^{1-5}$ It is also important that plastic working and machining of these steels are also relatively easy.

AHSSs are commonly used in the automotive industry because they make it possible to reduce the thickness of car-body sheets and car-body bearing elements, while enhancing their mechanical properties compared to conventional steels. An additional advantage of AHSSs is their relatively low price due to small amounts of alloying additives in steel. Despite the fact that the steels 
J. GÓRKA, A. OZGOWICZ: STRUCTURE AND PROPERTIES OF LASER-BEAM-WELDED JOINTS ...

Table 1: Chemical composition and mechanical properties of martensitic DOCOL 1200M steel

\begin{tabular}{|c|c|c|c|c|c|c|c|c|c|c|c|c|c|c|}
\hline \multicolumn{12}{|c|}{ Concentration of elements, $\%$} & \multicolumn{3}{|c|}{ Mechanical properties } \\
\hline $\mathrm{C}$ & $\mathrm{Si}$ & $\mathrm{Mn}$ & $\mathrm{P}$ & S & $\mathrm{Al}$ & $\mathrm{Nb}$ & V & $\mathrm{Ni}$ & $\mathrm{Cr}$ & $\mathrm{N}$ & $\mathrm{Ce}^{*}$ & $\begin{array}{c}\text { Tensile strength } \\
R_{\mathrm{m}}, \mathrm{MPa}\end{array}$ & $\begin{array}{c}\text { Yield point } R_{\mathrm{e}}, \\
\mathrm{MPa}\end{array}$ & $\underset{\%}{\text { Elongation } A_{80}}$ \\
\hline 0.113 & 0.22 & 1.58 & 0.01 & 0.002 & 0.035 & 0.016 & 0.01 & 0.04 & 0.04 & 0.006 & 0.39 & 1260 & 1060 & 5 \\
\hline
\end{tabular}

* Ce - carbon equivalent

were designed for being joined with bonding procedures, some of them still remain problematic for the development of the methods and optimum parameters of welding. ${ }^{6-12}$ It is a great challenge to weld high-strength DOCOL 1200M steel with a martensitic structure, primarily intended for manufacturing car bumpers, side beams and other user-safety elements of motor vehicles. In this respect, laser-beam welding has become increasingly important. Thanks to the technological progress and an increasing power of lasers, laser welding, one of the many techniques for joining materials, including simple and small items, for which this technique has proved to be successful due to its advantages, has now expanded into the area, which was until recently reserved only for conventional welding techniques.

The process of replacing the welding techniques used for a long time is often initiated by the use of new highstrength materials that require precise techniques and relevant technologies for joining to maintain highstrength properties of the base material. Due to highpower densities obtained in the impact area of a laser beam, laser welding allows single-pass welding of the sheets put together, without using butt welds with a square joint geometry and with relatively high welding rates (high performance). ${ }^{13-17}$

\section{EXPERIMENTAL PART}

The purpose of the examinations was to determine the effects of the linear energy of welding (from $25 \mathrm{~J} / \mathrm{mm}$ to $55 \mathrm{~J} / \mathrm{mm}$ ) on the properties and structure of butt joints of $1.8-\mathrm{mm}$ sheets of the high-strength low-alloy DOCOL $1200 \mathrm{M}$ steel with a martensitic structure welded with a laser beam without a filler material. For the actual che-

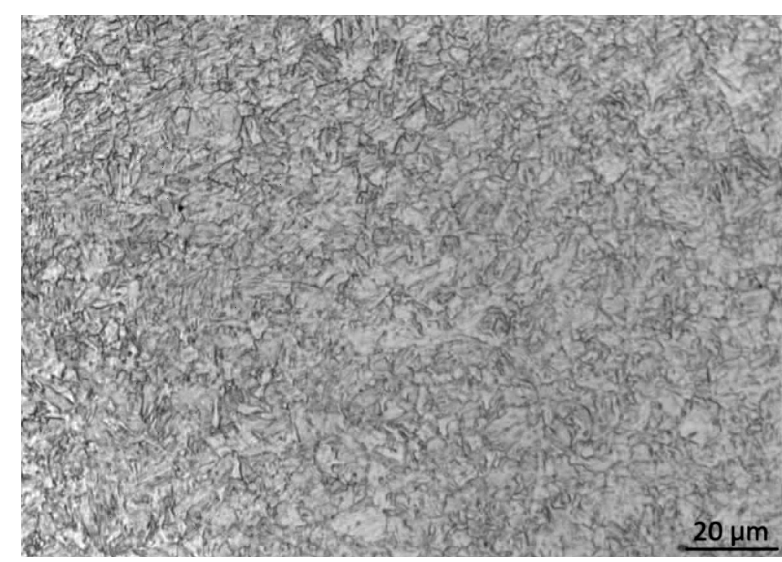

Figure 1: Microstructure of DOCOL 1200M steel mical composition and properties of the DOCOL $1200 \mathrm{M}$ steel (Table 1), and for its structure (Figure 1).

\subsection{Welding process}

The welded joints were made at a robotised station equipped with a KUKA KR 20/2HA industrial robot with a TRUMPF TruDisk 12002 disk-laser head (Figure 2). The focal length of the collimator lens was $f_{\mathrm{c}}=$ $200 \mathrm{~mm}$ and the focal length of the converging lens was $f_{\text {og }}=300 \mathrm{~mm}$. Optical-fibre cables with two different diameters, $d_{\mathrm{sw}}=0.2 \mathrm{~mm}$ and $d_{\mathrm{sw}}=0.4 \mathrm{~mm}$, were used for carrying the laser beam, providing for an additional modification of the linear energy of welding. The diameter of the laser-beam focus for both cases was calculated from Equation (1) and it was $d_{\mathrm{og}}=0.3 \mathrm{~mm}$ and $d_{\mathrm{og}}=0.6 \mathrm{~mm}$, respectively.

$$
d_{\mathrm{og}}=\frac{d_{\mathrm{sw}} \cdot f_{\mathrm{og}}}{f_{\mathrm{c}}}
$$

The welding process was conducted in the horizontal position using a butt weld with a square joint geometry. It was a shielded arc welding process with argon as the shielding gas supplied through a four-pipe nozzle at a flow rate of $20 \mathrm{~L} / \mathrm{min}$. The diameter of the laser-beam focus, beam power and welding rate were changed during the welding tests, Table 2. To reduce welding deformations, the sheets were tacked at three points (at the beginning, in the middle and at the end of the joint) before welding.

Table 2: Laser welding parameters for DOCOL 1200M steel with a thickness of $1.8 \mathrm{~mm}$

\begin{tabular}{|c|c|c|c|c|}
\hline $\begin{array}{c}\text { Joint } \\
\text { designa- } \\
\text { tion }\end{array}$ & $\begin{array}{c}\text { Power } \\
(\mathrm{W})\end{array}$ & $\begin{array}{c}\text { Melting } \\
\text { rate } \\
(\mathrm{mm} / \mathrm{min})\end{array}$ & $\begin{array}{c}\text { Linear } \\
\text { energy } \\
(\mathrm{J} / \mathrm{mm})\end{array}$ & $\begin{array}{c}\text { Diameter of the } \\
\text { laser-beam focus } \\
(\mathrm{mm})\end{array}$ \\
\hline 1.x & 2500 & 6000 & 25 & 0.3 \\
\hline $2 . \mathrm{x}$ & 3500 & 6000 & 35 & 0.6 \\
\hline $3 . \mathrm{x}$ & 1500 & 2000 & 45 & 0.3 \\
\hline 4.x & 1800 & 2000 & 55 & 0.6 \\
\hline
\end{tabular}

\subsection{Examinations of welded joints}

Following the visual inspection in accordance with PN-EN ISO 13919-1:2002, the welded joints were subjected to destructive testing to the following extent:

- tensile strength tests in accordance with PN-EN ISO 6892-1:2010 using a ZWICK/ROELL Z 330RED tensile-testing machine on samples taken in accordance with PN-EN ISO 4136:2011; 


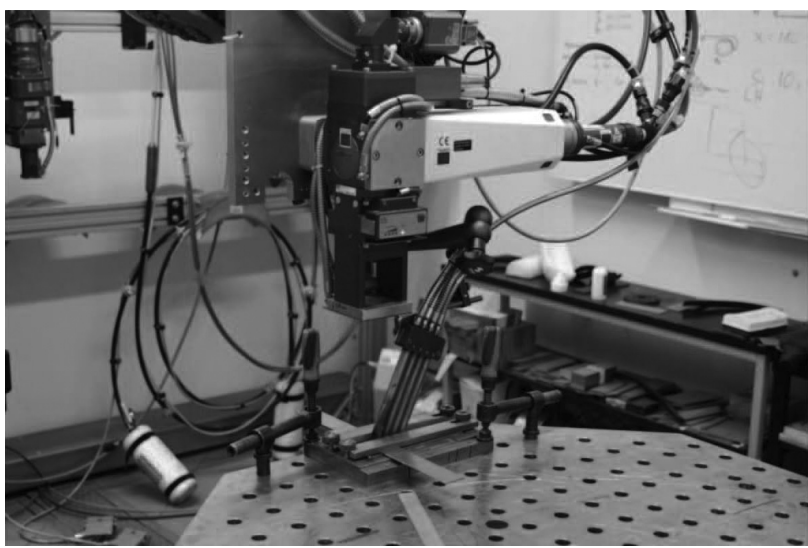

Figure 2: Position of the robotic laser welding used for the studies

- a transverse bend test of a butt joint with the tension from the face of the weld $(\mathrm{FBB})$ and a bend test of a butt joint with the tension from the root of the weld (RBB), in accordance with PN-EN ISO 5173:2010. The bend tests were carried out using the ZWICK/ ROELL Z 330RED machine with an additional bend-testing module;

- macroscopic metallographic examinations using an Olympus SZX9 stereoscopic light microscope; the test samples were etched with Adler's reagent;

- microscopic metallographic examinations using a NIKON ECLIPSE MA100 light microscope; the test samples were etched with nital;

- a hardness measurement using a Wilson Wolpert 401MVD Vickers device, at a load of $1 \mathrm{~kg}$, along one measuring line.

\section{RESULTS AND DISCUSSION}

The visual inspections of the welded joints revealed no welding defects coming out to the surface, such as cracks, porosity, incomplete fusions or a lack of joint penetration. The welded joints complied with the requirements for quality level B in accordance with ISO 13919-1. Only for the joints made with the linear energy of $25 \mathrm{~J} / \mathrm{mm}$, a linear offset, which reduces the quality level, can be observed. Neither did the macroscopic examinations reveal any welding irregularities in the weld area and HAZ (Figure 3). It can be observed that with an increase in the linear energy of the welding, the width of the weld and HAZ increased.

In each case, the microscopic examinations of the weld area revealed a martensitic structure, and with the increase in the linear energy of the welding, the size of the martensite needles also increased, especially in relation to the base material. In HAZ, the martensitic structure was tempered. The degree of tempering grew with the increase in the linear energy of the welding, Figure 4.

The analysis of the results of destructive testing of the laser-beam-welded butt joints of the DOMCOL

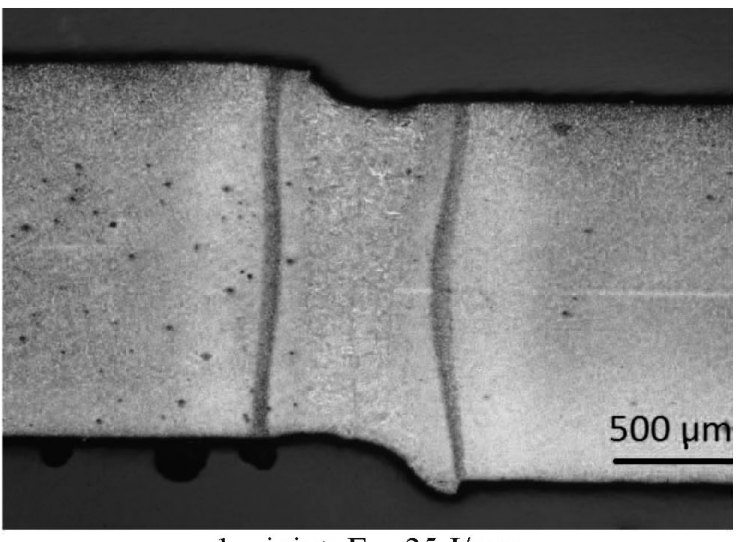

1.x joint; $\mathrm{E}=25 \mathrm{~J} / \mathrm{mm}$

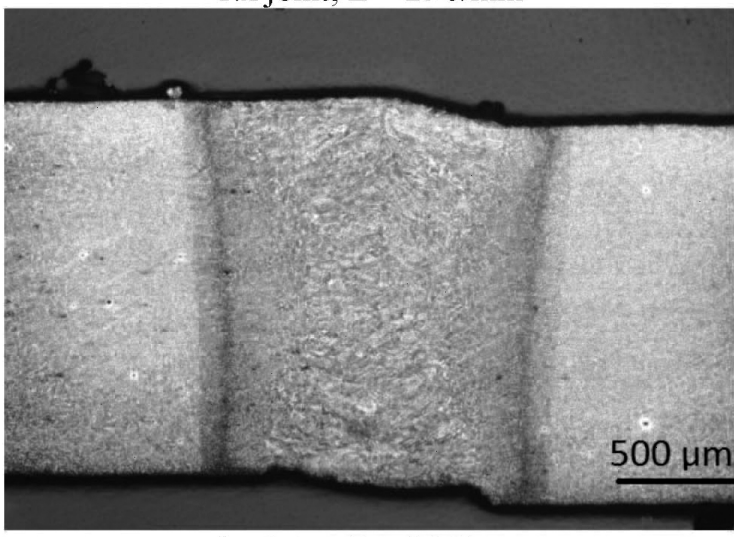

2.x joint; $\mathrm{E}=35 \mathrm{~J} / \mathrm{mm}$

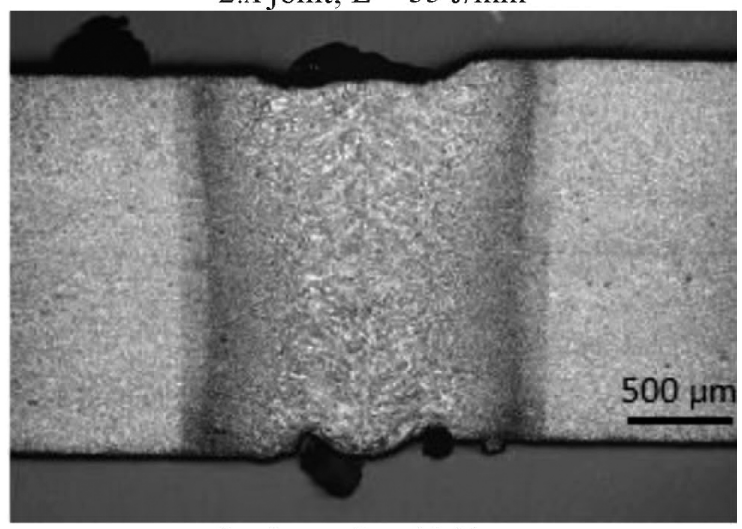

3.x joint; $\mathrm{E}=45 \mathrm{~J} / \mathrm{mm}$

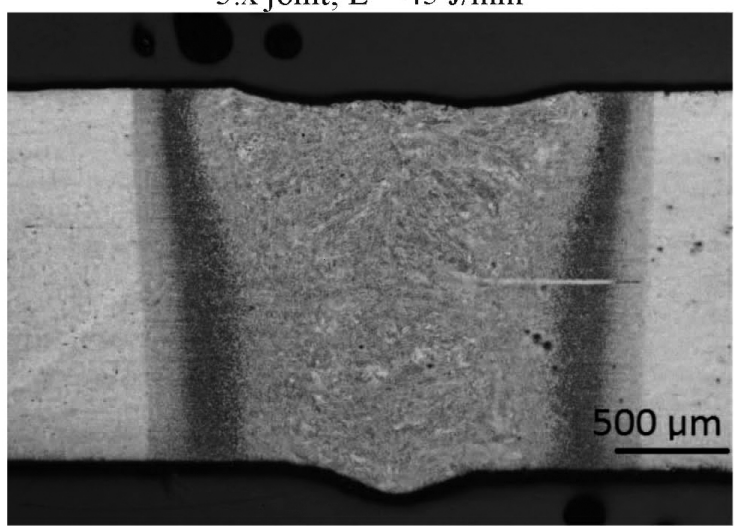

4. $\mathrm{x}$ joint; $\mathrm{E}=55 \mathrm{~J} / \mathrm{mm}$

Figure 3: Mechanical and plastic properties of laser-welded joints of steel DOCOL 1200M 

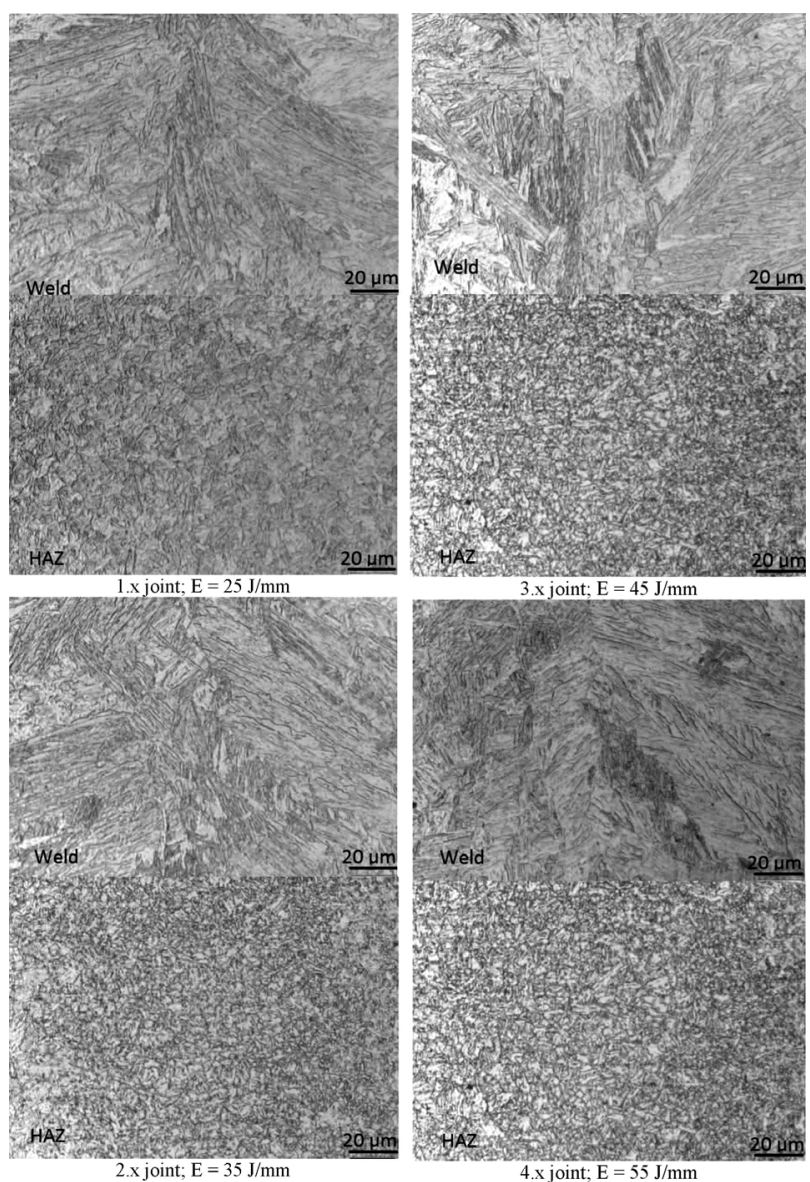

Figure 4: Microstructure of laser-welded joints of DOCOL 1200M steel

1200MC steel revealed that the test joints complied with the requirements of ISO 15614-11, Table 3. As the linear energy of the welding increased from $25 \mathrm{~J} / \mathrm{mm}$ to $55 \mathrm{~J} / \mathrm{mm}$, the tensile strength decreased from $1240 \mathrm{MPa}$ to $1100 \mathrm{MPa}$, with the tensile strength of the base material being at $1260 \mathrm{MPa}$. None of the tested welded joints showed any noticeable elongation. At low linear energies of the welding, a rupture took place in the base-material area. The increase in the welding energy resulted in the grain growth in HAZ where the rupture of joints was initiated. The static-bend test revealed that the highest plastic properties were shown by the joints made at the highest linear energy $(55 \mathrm{~J} / \mathrm{mm})$, for which a bending angle of about $140^{\circ}$ was obtained, Table 3 . With the reduction in the linear energy of the welding to 25 $\mathrm{J} / \mathrm{mm}$, plastic properties of the joints decreased and the obtained bending angles were about $70^{\circ}$.

The measurements of hardness HV1 confirmed the results of the microscopic metallographic examinations. In the area of the weld made at the lowest linear energy $(25 \mathrm{~J} / \mathrm{mm})$, the obtained hardness results were similar to the hardness of the base material, i.e., about $445 \mathrm{HV} 1$. With the increase in the linear energy of the welding, the weld hardness decreased to $430 \mathrm{HV} 1$ at $35 \mathrm{~J} / \mathrm{mm}, 420$ $\mathrm{HV} 1$ at $45 \mathrm{~J} / \mathrm{mm}$ and $410 \mathrm{HV} 1$ at $55 \mathrm{~J} / \mathrm{mm}$. In HAZ,

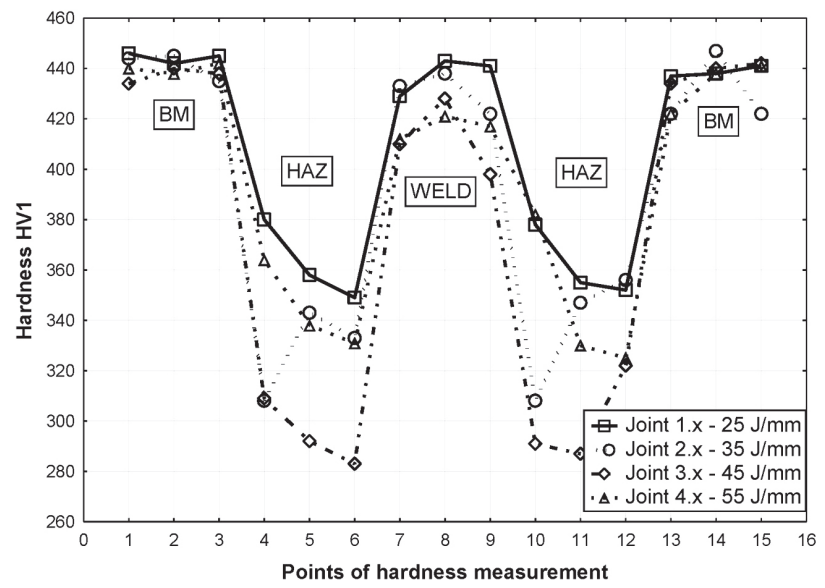

Figure 5: Distribution of hardness for laser-welded joints of DOCOL 1200M steel

which was tempered, the hardness also decreased with the increase in the linear energy of the welding, from 360 HV1 $(25 \mathrm{~J} / \mathrm{mm})$ to $340 \mathrm{HV} 1(35 \mathrm{~J} / \mathrm{mm}), 310 \mathrm{HV} 1$ (45 $\mathrm{J} / \mathrm{mm})$ and $280 \mathrm{HV} 1(55 \mathrm{~J} / \mathrm{mm})$, Figure 5.

Table 3: Mechanical and plastic properties of laser-welded steel DOCOL 1200M

\begin{tabular}{|c|c|c|c|}
\hline Tension* & \multicolumn{3}{|c|}{ Bending*, bending angle, ${ }^{\circ}$} \\
\hline$R_{\mathrm{m}}, \mathrm{MPa}$ & $\begin{array}{l}\text { Place of } \\
\text { rupture }\end{array}$ & Weld face & Weld root \\
\hline \multicolumn{4}{|c|}{ Joint $1 ; E=25 \mathrm{~J} / \mathrm{mm}$} \\
\hline 1240 & Base material & 68 & 69 \\
\hline \multicolumn{4}{|c|}{ Joint $2 ; E=35 \mathrm{~J} / \mathrm{mm}$} \\
\hline 1200 & Fusion line & 66 & 72 \\
\hline \multicolumn{4}{|c|}{ Joint $3 ; E=45 \mathrm{~J} / \mathrm{mm}$} \\
\hline 1150 & HAZ & 84 & 83 \\
\hline \multicolumn{4}{|c|}{ Joint $4 ; E=55 \mathrm{~J} / \mathrm{mm}$} \\
\hline 1120 & HAZ & 140 & 138 \\
\hline
\end{tabular}

Comments: none of the tested joints showed any noticeable elongation * the mean of two measurements

\section{CONCLUSIONS}

The examinations of laser-beam welding of the DOCOL 1200M steel with a thickness of $1.8 \mathrm{~mm}$ revealed that it is possible to make welds in compliance with the criteria specified by ISO 15614-11. Despite the high carbon equivalent of the DOCOL $1200 \mathrm{M}$ steel, it is possible to make laser-beam welded joints with high strength properties. In the weld area, all the joints are characterised by a martensite structure with a variable needle size, depending on the amount of the energy supplied. With an increase in the linear energy of the welding, the size of martensite laths increased. In HAZ, the base material was tempered, which resulted in the formation of a softened zone. The size of the weld and the softened zone in the examined joints increased with the increase in the linear energy of the welding. To reduce the area of the softened zone, the linear energies used should be as low as possible. The bend test revealed 
that the laser-beam welded joints of the DOCOL 1200M steel with the applied parameters were characterised by a low ductility in the joint area. However, the main operating property of this steel is its tensile strength. By using low linear energies of laser-beam welding, it is possible to produce welded joints with a strength equal to that of the base material, which is not achievable when arc welding the steels with such a high strength.

\section{REFERENCES}

${ }^{1}$ C. Lee, H. Shin, K. Park, Evaluation of high strength TMCP steel weld for use in cold regions, Journal of Constructional Steel Research, 74 (2012), 134-139

${ }^{2}$ M. Yurioka, Welding in the World, TMCP steels and their welding, 35 (1995) 6, 375-390

${ }^{3}$ J. Górka, Weldability of thermomechanically treated steels having a high yield point, Archives of Metallurgy and Materials, 60 (2015) 1, 469-475, doi:10.1515/amm-2015-0076

${ }^{4}$ A. Lisiecki, Welding of Thermomechanically Rolled Fine-Grain Steel by Different Types of Lasers, Archives of Metallurgy and Materials, 59 (2014), 1625-1631, doi:10.2478/amm-2014-0276

${ }^{5}$ M. Opiela, Effect of Thermomechanical Processing on the Microstructure and Mechanical Properties of Nb-Ti-V Microalloyed Steel, Journal of Materials Engineering and Performance, 9 (2014), 3379-3388

${ }^{6}$ D. Janicki, Fiber laser welding of nickel based superalloy Rene 77, Proc. of SPIE, Laser Technology 2012: Applications of Lasers, 87030S (2013), doi: 10.1117/12.2013428

${ }^{7}$ A. Lisiecki, Effect of heat input during disk laser bead-on-plate welding of thermomechanically rolled steel on penetration characteristics and porosity formation in the weld metal, Archives of Metallurgy and Materials, 61 (2016), 93-102, doi:10.1515/amm2016-0019
${ }^{8}$ A. Kurc-Lisiecka et al., Analysis of deformation texture in AISI 304 steel sheets, Solid State Phenomena, 203-204 (2013), 105-110, doi:10.4028/www.scientific.net/SSP.203-204.105

${ }^{9}$ A. Grajcar, M. Różański, S. Stano, A. Kowalski, Microstructure characterization of laser-welded Nb-microalloyed silicon-aluminum TRIP steel, Journal of Materials Engineering and Performance, 23 (2014) 9, 3400-3406

${ }^{10}$ A. Lisiecki, Welding of titanium alloy by disk laser, Proc. of SPIE, Laser Technology 2012: Applications of Lasers, 87030T (2013), doi:10.1117/12.2013431

${ }^{11}$ A. Grajcar, M. Różański, M. Kamińska, B. Grzegorczyk, Study on Non-Metallic Inclusions in Laser-Welded TRIP-Aided Nb-Microalloyed Steel, Archives of Metallurgy and Materials, 59 (2014), 1163-1169, doi:10.2478/amm-2014-0203

${ }^{12}$ D. Janicki, Disk laser welding of armor steel, Archives of Metallurgy and Materials, 59 (2014), 1641-1646, doi:10.2478/amm-2014-0279

${ }^{13}$ J. Górka, Study of structural changes in S700MC steel thermomechanically treated under the influence of simulated welding thermal cycles, Indian Journal of Engineering and Materials Sciences, 22 (2015), 497-502

${ }^{14}$ M. Żuk, J. Górka, A. Czupryński, M. Adamiak, Properties and structure of the weld joints of quench and tempered $4330 \mathrm{~V}$ steel, Metalurgija, 55 (2016) 4, 613-616

${ }^{15}$ M. Charleux, W.-J. Poole, M. Militzer, Precipitation behavior and its effect on strengthening of an HSLA-Nb/Ti steel, Metallurgical and Materials Transactions A, 32 (2001), 1635-1647

${ }^{16}$ J. Górka, Analysis of simulated welding thermal cycles S700MC using a thermal imaging camera, Advanced Material Research, 1036 (2014), 111-116

${ }^{17}$ Y. Crowther, M. Green, P. Mitchell, The Effect of Vanadium and Niobium on the Properties and Microstructure of the Intercritically Reheated Coarse Grained Heat Affected Zone in Low Carbon Microalloyed Steels, ISIJ International, 41 (2001), 46-55 